DOI https://doi.org/10.32782/2305-9389/2020.22.10

УДК 94(100):37.0

Набока Сергій,

кандидат історичних наук, доиент, доцент кафедри історії світового українства історичного факультету Київського національного університету імені Тараса Шевченка

\title{
ОСОБЛИВОСТІ РОЗВИТКУ ОСВІТИ В НОВІТНІЙ ЧАС
}

У статті проаналізовано основні тенденції розвитку освітніх процесів із кіния ХІХ до початку XXI століття. У результаті проведеної наукової розвідки, з'ясовано основні чинники, щзо визначили еволюцію, формування та функиіонування системи освіти у цей період. Визначено, щчо поступове становлення у світі з другої половини ХІХ століття системи загальної масової освіти зумовлювалося передусім впливом ключових військовополітичних та сочіально-економічних чинників. Із удосконаленням озброєння держави вимушені були перейти до масових призовних армій. В умовах ускладнення зброї, а також економічної неспроможності довго тримати на військовій службі мільйони солдатів держави відтепер потребували мінімально грамотних призовників. Окрім того, у світі у ичей час утвердився індустріальний тип економіки, щчо вимагала великої кількості хоча б початково грамотних людей. Необхідність розиирити контроль над громадянами також відігравала певну роль у встановленні державної системи освіти.

У дослідженні висвітлено характерні риси «індустріальної системи освіти», щчо домінувала у світі з кінця ХІХ до кіния XX століття, а також чинники, щзо детермінували їх існування. Ознаками «індустріальної системи» були: масовість, доступність, стандартизація знань, ідеологізованість навчального процесу, орієнтація на «середнього учня», колективний підхід, класно-урочна система викладання, значна вага виховання, дисципліни та покарань.

Окрім того, у роботі проаналізовано тендениії еволючійних змін в освітній сфері, щзо стають невід’ємною частиною сучасної системи освіти ХХІ століття.

Ключові слова: загальна освіта, масове навчання, класно-урочна система, стандартизація знань, ідеологізованість, вузька спеціалізація, Інтернет, онлайн-урок, глобалізація освіти.

\section{Naboka Serhii. Specific features of education development in the Modern Age}

The article analyzes the main trends in the development of educational processes from the late XIX century to the early XXI century. The main factors which determined the evolution, formation and functioning of the education system during this period are identified as the result of scientific investigation.

Author defined that the gradual establishment of general mass education system in the world since the second part of XIX century was explained primarily by the influence of the key military-political and socio-economic factors. With the improvement of weaponry, states were forced to switch to mass conscription armies. With the complication of weapons, as well as the economic inability to keep the millions soldiers in military service for a long time, the state now required minimally literate conscripts. Moreover, in the world at this time, an industrial type of economy had been established, which required large numbers of at least initially literate people. The need to broaden control over citizens also played a role in the establishment of the national education system.

The study highlights the characteristics of the "industrial education system" that dominated in the world from the late nineteenth to the late twentieth century, as well as the factors determining their existence. There were typical attributes of the "industrial system": massiveness; accessibility; standardization of knowledge; ideologization of the educational process; focus on the "average student"; collective approach; class-lesson system of education; significant weight of upbringing, discipline and punishment.

In addition, the article analyzes the trends of evolutionary changes in the educational sphere, which are becoming an integral part of the contemporary education system of the XXI century.

Key words: general education, mass education, class-lesson system, standardization of knowledge, ideologization, subspecialization, Internet, online-lesson, globalization of education.

Сучасний період історії характеризується процесами різких і радикальних перетворень у всіх сфеpax життя людей. Кардинально та швидко відбуваються зміни в технічному, соціальному, економічному та культурному укладі суспільства. Стрімкі нововведення, безумовно, відбиваються й на освітній сфері, котра також змушена еволюціонувати в прискореному темпі, щоб відповідати новим потребам життя та вимогам часу. Таким чином, аналіз чинників розвитку освітніх процесів в історії стає досить актуальним і для сьогодення.

Дослідженню освітньої проблематики присвячено роботи видатних учених Дж. Брунера [1], Дж. Дьюї [2], I. Ілліча [3] та ін. Однак у своїх працях вони висвітлюють лише окремі аспекти цих 
процесів. Вивчення ж загальних закономірностей, а також специфіки розвитку освітніх систем потребує окремого дослідження.

Метою даної роботи є розгляд особливостей еволюції освіти в новітній час. У роботі використовуються проблемно-хронологічний та історико-системний методи, що дало змогу об'єктивно підійти до розгляду даної проблеми.

У XIX-XX століттях у суспільній думці народів західної цивілізації утверджується культ знань, побутує віра в універсальні можливості науки та прогресу. Із кінця XIX століття в Свропі та Північній Америці (а згодом і в усьому світі) поступово формується «індустріальний» тип освіти. Звичайною практикою, прийнятою на державному рівні, стає форма загальної, доступної для всіх верств населення масової системи освіти. Спочатку вона була, як правило, платною, необов'язковою і надавалася переважно лише на початковому рівні. Та й займалися нею здебільшого церковні, приватні і філантропічні організації [4, с. 512]. Однак згодом цю сферу перебирає до своїх функцій держава, а освіта (як початкова, так і середня) стає обов'язковою, масовою і безкоштовною.

Аналізуючи причини цього явища, можна виділити два головних чинники, що визначально вплинули на утвердження системи масової освіти в XX столітті.

По-перше, дія військово-політичних чинників зумовлювала запровадження все більшої грамотності серед населення, оскільки з другої половини XIX століття прогрес у сфері озброєнь призвів до такого стану речей, коли відносно нечисленні рекрутські чи наймані армії вичерпувалися за пару місяців боїв, адже використання скорострільних гармат, гвинтівок, кулеметів, призводило до жахливих втрат живої сили. А швидко набрати й, головне, вивчити нових бійців було практично неможливо. Окрім того, досить складна зброя і новітня тактика військових дій вимагали певної грамотності серед солдатів.

Таким чином, великі держави переходять до масових призовних армій. Однак для того щоб швидко навчити призовників користуватися складною зброєю і виконувати непрості тактичні прийоми, необхідно було, щоб вони вже були мінімально грамотні. Мучитися з колишнім сільським кріпаком, котрий навіть, бувало, не розрізняв «право-ліво» важко, дорого, нераціонально та й ніколи. Отже, введення хоча б мінімальної грамотності населення частково диктувалося цими чинниками.

Проте головні причини неухильного запровадження системи масової освіти зумовлювалися впливом масштабних соціально-економічних чинників. Економіка західної цивілізації стає все більш складною, навколо відбувається промислова революція. Основою багатства відтепер були вже не земельні маєтки, а індустрія та фінанси. Фабрики, заводи, банки стають головними ознаками промислово розвинутих країн. Вони робили їх передовими в усіх сферах життя, у тому числі й у військовій, адже без ефективної зброї та залізниць виграти війну ставало неможливим. Ганебна поразка Російської імперії в Кримській війні наочно продемонструвала всі переваги сучасних держав.

Однак індустріальна капіталістична економіка (та й паралельний розвиток супутніх галузей) усе більше потребувала грамотних людей. Після низки буржуазних революцій в Свропі та Північній Америці при владі в країнах цих континентів закономірно утвердилися «капітани економіки» - буржуа. Таким чином, для забезпечення своїх економічних приватних потреб (та й державних теж, оскільки держава як усередині країни, так і на міжнародній арені задовольняла, захищала та лобіювала перш за все інтереси правлячого класу буржуазії) поступово в більшості країн упроваджується система масової загальної освіти. Спочатку лише початкової, платної й не всім доступної. Однак згодом з ускладненням економіки та розвитку соціальних прав людей освіта стає безкоштовною, доступною для всіх (навіть обов'язковою), і не лише початкова, а й середня.

Бюрократично-тоталітарні деспотії (як, приміром, СРСР) також уводять систему масової та безкоштовної освіти, тому що крім вимог відповідати соціально-ідеологічним аспектам свого устрою, воєнні потреби та інтереси індустріальної економіки також нагально диктували цю необхідність.

Загалом масова система освіти, яка набула максимального поширення в XX сторіччі, мала свої типові риси, характеристики і методику викладання.

Ще наприкінці XIX століття для отримання можливості швидко і дешево забезпечити широке запровадження початкової грамотності серед населення вводиться класно-урочна система викладання [5, с. 119], де один вчитель,і працює з цілим класом (а то і з кількома), надаючи уроки елементарної граматики, лічби, читання... Такий підхід давав змогу поставити освіту «на конвеєр», гарантуючи масовість, всеохоплюваність, стандартизацію.

Таким чином, ще однією з помітних рис «індустріальної освіти» (окрім, звичайно, ії масовості) була стандартизація знань, що зумовлювалася самим типом освіти. Окрім того, всі учні країни, як правило, вчилися по однакових підручниках, предметах, учбових програмах, методиках. Це для держави виходило дешевше, та й у соціальному та політичному відношенні такий стан речей мав певні вигоди, 
оскільки створювався єдиний культурний простір, зменшувалися соціальні протиріччя та розрив між станами суспільства, а держава простіше могла контролювати і впливати на громадян.

До того ж у цьому аспекті можна відзначити характерну ознаку масової освіти XX сторіччя - iї ідеологізованість. Практично в усіх країнах (особливо до середини століття) в освіті яскраво був присутній ідеологічний складник. Іншими словами, дітям не лише давали певні знання та навички, а й інтенсивно обробляли їм мізки в домінуючому в державі політичному дусі. Яка саме ідеологія втовкмачувалася у свідомість підлітків (монархічна, націоналістична, релігійна, фашистська, комуністична), залежало, власне, від правлячого в даній країні політичного режиму. Найбільше ідеології, звичайно, було представлено у викладанні гуманітарних дисциплін.

Відповідно, певною ознакою такої освіти, було й те, що вона займалася власне не лише навчанням дітей, а й обов'язково їх вихованням. Вимоги до цього аспекту навчання були досить суворі. За поведінку ставили оцінки. За негативних характеристик могли виключити з навчального закладу, дати «вовчий білет», перекрити подальші перспективи для «нелояльного» учня чи студента [6, с. 302].

Ще однією рисою індустріальної системи освіти, були високі вимоги дотримання дисципліни. Школярі, студенти, учні ремісничих училищ носили певну форму, виконували правила розпорядку, відбували чергування. Ну і, звичайно, існувала ціла низка моральних та фізичних покарань. Фактично аж до Другої світової війни в багатьох країнах фізичні покарання досить часто застосовувалися в навчальному процесі [7, с. 394].

За такої масової, дешевої і стандартизованої системи освіти вчителі намагалися добитися, щоб учні засвоїли певний обсяг знань, фактів, формул. Проте творчість, критичність, ініціативність, індивідуалізм, власна думка учня чи студента не віталися. Це зумовлювалося як об'єктивними, так і суб'єктивними обставинами. Звичайно, педагоги, які були вимушені працювати з великою масою учнів, реально практично не мали можливості, займатися індивідуальним підходом, їм головне було забезпечити «середній рівень» засвоєння більшістю навчальної програми в уніфікованому вигляді.

Окрім того, власне й сама індустріальна економіка того часу потребувала маси грамотних та кваліфікованих виконавців: техніків, адміністраторів, робітників. До того ж у той період у світі домінували переважно політичні режими релігійно-монархічного або авторитарно-тоталітарного типу, яким, звісно, потрібен був слухняний і лояльний загал «однакових» громадян, а не критично налаштованих та мислячих особистостей.

Проте поруч із мінусами цієї освіти (iї ідеологізованістю, стандартизацією, системою покарань, нерідко відірваністю від життя отриманих теоретичних знань, відсутністю ініціативності та критичного підходу до розвитку індивідуумів) вона мала й безперечні плюси. Це, безумовно, масовість та доступність освіти, що сприяла соціальним ліфтам у суспільстві для всіх людей незалежно від їх походження. До того ж така освіта давала школярам досить грунтовні знання з предметів [8, с. 432]. А головне - під час подачі знань практикувався системний підхід та принцип «від простого до складного» у викладанні учбового матеріалу з будь-якої дисципліни [9, с. 122]. Це формувало у дитини логічну та зрозумілу картину світу, сприяло розвитку у неї причинно-наслідкових зв'язків явищ та подій.

Проте з другої половини XX століття відповідно до змін у соціально-економічному, суспільно-політичному та культурно-технологічному житті система освіти також поступово еволюціонує, набуваючи нових рис та характеристик. Постіндустріальна економіка висувала нові вимоги до освітнього процесу. А розвиток НТР та прискорення ритму життя в усіх сферах суспільного буття створювали нові передумови та можливості. В освіті «постіндустріального суспільства» з'являються нові методи та інструменти навчання, які докорінно відрізняють ії від «індустріальної освіти» минулого.

Характерною тенденцією сучасної системи освіти стає все більша різноманітність навчальних закладів, підручників, учбових програм, спеціальностей [10, с. 490]. Учні та студенти у цьому відношенні мають набагато ширший вибір, аніж їхні попередники. Більша розмаїтість та ускладненість сучасної економіки, підняття рівня життя й суспільного багатства, зростання рамок соціальної автономії та свобод зумовлюють і більшу розмаїтість «освітніх пропозицій».

Закінчення «холодної війни», зростання добробуту людей, розвиток комунікацій та транспорту, а головне - світові процеси глобалізації детермінують також і глобалізацію освіти. Освітні системи різних країн світу стають усе більш схожими. Окрім того, у глобальному та відкритому світі люди стають більш мобільними. Це відбивається не лише в тому, що все більше студентів із різних країн навчаються за кордоном, а й від того, що в глобальній економіці вихідці з різних країн повинні бути готовими працювати в будь-якому куточку світу. Таким чином, працівники повинні легко перенавчатися та адаптуватися скрізь. Відповідно, вплив усіх цих чинників призводить до все більшої «універсалізації» освітніх систем. 
У сучасній освіті в минуле практично відходять аспект виховання, елементи дисципліни та покарань. Учнів зараз практично не виховують, дисциплінарні моменти зводяться до мінімуму (навіть однакова форма для школярів вже необов'язкова), а можливі покарання зводяться максимум до розмови з батьками. Ідеологічна «обробка» учнів та студентства також мінімізується. У науці й освіті її присутність (порівняно з минулим періодом) кардинально зменшилася.

Якісні зміни відбуваються і в методах та формах навчання. Із розвитком комунікацій та глобалізації з'явилися нові технологічні можливості, котрі все більше застосовуються у сфері освіти. Так, завдяки комп’ютерним технологіям та Інтернету все більшої популярності набувають онлайн-курси, дистанційне навчання, заняття по скайпу. Це економить час та розширює можливості. Навіть наповненість аудиторного навчання змінюється. Якщо раніше майже всю інформацію учні та студенти отримували від лектора чи студіюючи підручники, то зараз усе більше перевага віддається їх самостійному навчанню. Тим більше що учні можуть нині вільно та оперативно здобувати величезну кількість будь-яких даних через Інтернет, легко їх обробляти. Студентам нині непотрібно витрачати час, шукаючи дефіцитні книги в бібліотеках. Окрім того, завдяки закінченню «холодної війни» та глобалізації маса інформації зараз знаходиться у вільному доступі. Викладачі все більше в навчанні не стільки дають учням певний фактаж, як учать студентів аналітиці та направляють їх, стимулюючи до самостійної роботи.

Нові форми отримання інформації проявляються не лише у цьому. Учень чи студент тепер може свідомо вибирати ті інструменти та способи навчання, які йому зручніше й вигідніше використовувати, адже він тепер може сприймати інформацію не лише через традиційні підручники, а й в аудіочи відеоформаті. Навчальні ролики можна прослуховувати чи дивитися навіть у своєму смартфоні. Та й традиційне конспектування лекцій відходить у минуле. Урок учителя можна записати на диктофон чи зафіксувати на своєму планшеті.

Ще однією характерною рисою сучасної системи освіти є тенденція до ï все більш вузької спеціалізації. I це досить закономірно. Постіндустріальна економіка стає все більш складною і гнучкою. Ïї спеціалізація також збільшується. Вимоги до рівня та необхідного обсягу знань у конкретній професії зростають. Відповідно, звужуються можливості людини до якісного та ефективного засвоєння надто широкого професійного спектру знань і навичок. Людям, щоб навіть бути на рівні змін у своїй спеціальності, потрібно постійно перенавчатися. Отже, освіта вслід за соціально-економічним попитом суспільства стає також усе більш вузькопрофільованою.

Калейдоскопічність та фрагментарність подачі знань у сфері середньої освіти, на жаль, теж стають ознакою сучасного навчання. Так дітям простіше, цікавіше та легше сприймати урок. А системність та великий обсяг інформації вважаються тепер необов'язковими та надлишковими. Та й запам'ятовувати масу інформації немає вже великої потреби, оскільки ії можна швидко та легко завжди «освіжити» чи отримати, звернувшись до Інтернету.

Змінюється й мета самої освіти. Стає набагато важливішим розвинути у студента аналітичні здібності, вміння критично підходити до джерел, робити висновки, знаходити інформацію, виробити в учня навички ініціативності та самостійності, стимулювати його творчий підхід, звичку до постійного перенавчання та здобутку нових знань.

Еволюція освіти, що виступає невід’ємним складником загальних змін у світі, проявляється й у тому, що 3'являються вимоги до вироблення в учнів нових, сучасних навичок. Так, уміння користуватися сучасними електронними пристроями стає все більш необхідним для ефективного навчання, обробки та отримання інформації.

Водночас, прослідковуючи тенденції розвитку інформаційної сфери та освітньої галузі, можна відзначити, що низка звичних для нас навичок і способів здобуття знань використовуватиметься все рідше. Наприклад, раніше вміння писати виступало однією з фундаментальних основ грамотності, оскільки велику частину інформації люди вимушені були передавати чи використовувати в рукописному вигляді. В освіченої людини цінувалися каліграфічні навички письма, оскільки розбирати погані почерки було незручно й важко.

Однак зараз уміння писати ручкою на папері стає все менш потрібним та неактуальним, тому що практично вся інформація зараз фіксується, передається та зберігається в електронному чи друкованому вигляді. Із розвитком комунікаційних засобів та широкої доступності принтерів такий стан речей $\epsilon$ цілком закономірним. Можна стверджувати, що дана тенденція в освіті також буде зміцнюватися, тобто учні все більше використовуватимуть не традиційні ручки, а планшети, смартфони чи ноутбуки.

Так само, скоріше за все, питома вага годин, що відводяться для навчання школярів навичкам рахунку на папері чи в умі, буде неухильно знижуватися. Із насиченням населення мобільними 
телефонами та смартфонами, які за секунди роблять підрахунки будь-якої складності, це стає непотрібним і втрачає сенс.

Ще один звичний для нас бік освіти й життя також зазнає незворотних змін. Донедавна люди більшість знань отримували через читання. Однак із розвитком нових технологій та засобів комунікації люди читають усе менше. Причому не лише паперових книг, а й електронних текстів. Читання все менше використовується як у навчанні, так і задля розваги.

І це відбувається не лише тому, що зараз дістали якісного розвитку та стали широко доступні й зручні нові ефективні альтернативні засоби отримання інформації: аудіо, відео, Інтернет. Справа дещо складніша. Для дітей змалку це було не стільки засобом навчання, скільки розвагою. Прилучаючись до процесу читання і поглинаючи спочатку казки, а згодом пригоди, детективи, романи, фантастику, дитина відкривала для себе новий великий світ і звикала отримувати інформацію саме цим шляхом.

Однак в останні десятиріччя ситуація кардинально змінилася. Із розвитком технологій, посиленням процесів глобалізації та появою нових форм відпочинку сфера дозвілля стала надзвичайно різноманітною та ефектною. Діти відразу отримують море легких і яскравих розваг: комп'ютерні ігри, маса дитячих передач та мультиків у телевізорі, аудіо- та відеоролики в смартфонах, величезні можливості спілкування завдяки новим комунікаційним пристроям. Далі йдуть фільми жахів, бойовики, еротика, які апелюють до найпростіших та найпримітивніших інстинктів людини і не потребують від споживача ніякої інтелектуальної чи культурної підготовки. На цьому тлі читання, звичайно, виглядає нудним і не може витримати суперництва $з$ яскравими та ефектними конкурентами, тому підлітки хоча й уміють читати, однак смаку та звички до читання не виробляють. Не має сумніву, що ці моменти враховуватимуться в освітній сфері. Кількість, обсяг, складність підручників знижуватимуться. Натомість вага аудіо- та відео навчальних матеріалів буде збільшуватиметься.

1. Брунер Дж. Процесс обучения. Москва : АПН РСФСР, 1962.82

2. Дьюи Дж. Демократия и образование. Москва : Педагогика пресс, 2000. 382 с.

3. Иллич И. Освобождение от школ. Пропорциональность и современный мир. Москва : Просвещение, 2006.160 с.

4. Ге Ф. История воспитания и образования. Москва : Тихомиров, 1912. $660 \mathrm{c.}$

5. Джуринский А.Н. История педагогики и образования : в 2-х ч. ; 3-е изд., испр. и доп. Москва : Юрайт, 2019.282 с.

6. Монро П. История педагогики / пер. с англ. Ч. И. Новое время ; 4-е изд. Москва ; Петроград : ГИЗ, 1923.342 с.

7. І Історія педагогіки / за ред. М.С. Гриценка. Київ : Вища школа, 1973. 448 с.

8. Пискунов А.И. История педагогики и образования от зарождения воспитания в первобытном обществе до конца ХХ в. Москва : Сфера, 2009. 496 с.

9. Корнетов Г.Б. Всемирная история педагогики : учебное пособие. Москва : Рос. откр. ун-т, 1994. 140 с.

10. Князев Е.А. История педагогики и образования : учебник и практикум для академического бакалавриата. Москва : Юрайт, 2019. 505 с. 